\title{
Correction to: The obesity paradox and osteoporosis
}

\author{
Angelo Fassio ${ }^{1}$ (D $\cdot$ Luca Idolazzi $^{1} \cdot$ Maurizio Rossini ${ }^{1} \cdot$ Davide Gatti $^{1} \cdot$ Giovanni Adami $^{1} \cdot$ Alessandro Giollo $^{1}$. \\ Ombretta Viapiana ${ }^{1}$
}

Published online: 2 May 2018

(c) Springer International Publishing AG, part of Springer Nature 2018

\section{Correction to: \\ Eating and Weight Disorders - Studies on Anorexia, Bulimia and Obesity https://doi.org/10.1007/s40519-018-0505-2}

Unfortunately, the author's first name and the family name were swapped and published in the original publication.

The complete corrected author group is given below.

Angelo Fassio; Luca Idolazzi; Maurizio Rossini, Professor; Davide Gatti, Professor; Giovanni Adami; Alessandro Giollo; Ombretta Viapiana.

The original article has been corrected.

The original article can be found online at https://doi.org/10.1007/ s40519-018-0505-2

Angelo Fassio

angelo.fassio@yahoo.it

1 Rheumatology Unit, University of Verona, Policlinico G.B.

Rossi, piazzale A. Scuro, 37134 Verona, Italy 